\title{
Benjamin Disraeli and the Myth of Sephardi Superiority
}

\author{
Todd M. Endelman
}

On the day following Benjamin Disraeli's death, Lady Battersea (1843-1931), daughter of Sir Anthony de Rothschild (1810-1876), wrote to her husband that their late friend had been "not only loyal to his Queen and country, but also to the race from which he sprung," adding that "his racial instincts were his religion and he was true to that religion until he drew his last breath."' Lady Battersea's observation - that Disraeli's ideas about race were central to his self-definition - was consistent with contemporary interpretations of his character and beliefs. Friend and foe alike routinely linked his political behavior and thinking to his ethnic background, to what Lady Battersea called "his racial instincts." In the century following his death, however, his biographers, as well as historians and political scientists, hesitated to view his racial concerns as central to his identity and career, preferring to ignore them or at least minimize their importance. In his biographical triptych Burke, Disraeli, and Churchill (1961), Stephen Graubard, for example, though prepared to acknowledge Disraeli's interest in race, confessed to not knowing what to make of it. "It is difficult to understand," he admitted, "why Disraeli charged Sidonia with another teaching mission - to instruct Coningsby in the greatness of the Jewish race." With less hesitation, his biographer Robert Blake dismissed Disraeli's Jewishness in favor of the Italian "streak" in his character. If national or racial stereotypes were to be introduced at all, Blake believed, then the traits associated with the Mediterranean character were more dominant: pride, vanity, flamboyance, generosity, emotionalism, quarrelsomeness, extravagance, theatricality, an addiction to conspiracy, and a fondness for intrigue. Indeed, in Blake's view, Disraeli's financial ineptitude demonstrated the weakness of the Jewish element in his makeup. ${ }^{2}$

The first historian or political scientist in this century to accord Disraeli's racial ideas their due was Hannah Arendt, who, over four decades ago in The Origins of Totalitarianism (1951), suggested that Disraeli's declaration of Jewish racial 
chosenness was a strategy to combat his own sense of social inferiority. In her view, he was acutely sensitive to his status as an outsider in upper-class Tory circles and, to compensate, invented a myth of Jewish racial superiority. ${ }^{3}$

It was not Hannah Arendt, however, but Isaiah Berlin who reestablished for historical scholarship the central place of racial thinking in Disraeli's sense of self. In his presidential address to the Jewish Historical Society of England in 1967, in which he compared the links between ideology and identity in Disraeli and Marx, Berlin offered what is still the most elegant and authoritative exposition of this interpretation. Published in at least three different forums in English and translated into several other languages as well, his lecture described how Disraeli overcame a serious obstacle to his career - his Jewish background - by inflating it into a claim to noble birth. Disraeli "needed to do this," Berlin explained, "in order to feel that he was dealing on equal terms with the leaders of his family's adopted country, which he so profoundly venerated."4 As a result, in part, of the diffusion of this interpretation, there is now a consensus that Disraeli's racial ideas cannot be dismissed as irrelevant. Paul Smith's lecture to the Royal Historical Society on Disraeli's politics (1986), John Vincent's short account of Disraeli's thought in the Oxford Past Masters series (1990), and Stanley Weintraub's full biographical treatment (1993) are testimony to the reintegration of Disraeli's Jewish chauvinism into evaluations of his life and work. ${ }^{5}$ Reviewers of Weintraub's biography, while critical at times of his treatment of Victorian politics, have not balked at his restoration of Disraeli's Jewish concerns to center stage. ${ }^{6}$

In these and other accounts of Disraeli's Jewishness, ${ }^{7}$ one curious current remains unexplored - his use of the long-lived myth of Sephardi superiority, a myth that originated in medieval Spain and later migrated to western and northern Europe with the expansion of the Sephardi diaspora. The core of the myth, which remained more or less constant over the centuries despite changes in its external details, was the belief that Jews from the Iberian peninsula were different in kind from other Jews, that they were superior by virtue of their culture, learning, wealth, descent, manners, or, indeed, even blood. Illuminating this theme in Disraeli's racial thought and viewing it in a broad historical context brings his construction of Jewishness into clearer focus. But, even more so, it makes his chauvinism seem less curious. It suggests that what can be viewed - and dismissed - as personal and aberrant was, instead, a reworking of a wellestablished Sephardi tradition.

As is well known, Disraeli was not, in a strict sense, a Spanish or Portuguese Jew. His four grandparents or their parents were Italian-born. However, his grandmothers, Sarah Shiprut de Gabay Villa Real D'Israeli (1743-1825) and Rebecca Rieti Basevi (d. 1798), came from Iberian families that had settled in Italy in the late fifteenth century or thereafter. Thus, of his eight 
great-grandparents, three had Spanish or Portuguese antecedents; the other five were from native Italian stock or from Ashkenazi families that migrated there in the late medieval period. ${ }^{8}$ But since there were too few Italian Jews in London to sustain their own congregation, his relations who settled there associated with the well-established Spanish and Portuguese synagogue in Bevis Marks. This, rather than knowledge about his grandmothers' families, facilitated his romantic identification with Iberian Jewry.

In Disraeli's telling of his family history, as recorded in a memoir of his father for a new edition of The Curiosities of Literature (1849), his ancestors fled from Spain at the end of the fifteenth century and settled in Venice. There they flourished as merchants for two centuries, before his great-grandfather Disraeli, impressed by the commercial dynamism and religious tolerance of Hanoverian England, sent his youngest son to London in the mid eighteenth century. In this construction of his family background, which was as much fiction as fact, Disraeli enhanced both the grandeur and demographic strength of the London Sephardim at the time. According to his account, the Jewish families then settled there were "all of them Sephardim" who had been driven "from their pleasant residences and rich estates in Arragon [sic], and Andalusia, and Portugal." Ashkenazim, who, in fact, outnumbered Sephardim by the 1720s, were, in Disraeli's account, "then only occasionally stealing into England." Coming from "an inferior caste," they were kept at arm's length by the wealthy Sephardim. ${ }^{9}$

In conversation and correspondence as well, Disraeli identified himself with Spanish and Portuguese Jews and emphasized their superiority. Walking at Lord Carrington's park one cold day in January 1851 with Edward Stanley, eldest son of the Earl of Derby, he remarked that the one obstacle to the return of the Jews to the Land of Israel was "the existence of two races among the Hebrews, of whom one, those who settled along the shores of the Mediterranean, look down on the other, refusing even to associate with them." He called "the superior race," Stanley noted in his diary, "Sephardim."10 In letters to Sarah Brydges Willyams (ca. 1780-1863), the childless widow of Sephardi ancestry whose fortune he inherited, he wrote often of their shared background, of their common descent from the aristocratic Laras, of "the mysterious sympathy" that bound them together. ${ }^{11}$ And in 1844 he wrote to his fellow Tory MP Richard Monckton Milnes, then visiting Berlin, that although German Jews were "now the most intelligent of the tribes" they did not "rank high in blood," not being Sephardim. ${ }^{12}$

That Disraeli bestowed Sephardi origins on the international banker Sidonia in his Young England novels Coningsby (1844) and Tancred (1847) was no accident. "Descended from a very ancient and noble family of Arragon [sic], that, in the course of ages, had given to the state many distinguished citizens,"13 the multi-talented Sidonia acts as spokesman for Disraeli's racial and Jewish fantasies and as representative of those traits - worldliness, intellect, natural 
grace, social knowledge, wealth - with which Disraeli longed to be identified. When Sidonia makes an entrance at Lord Monmouth's country home for dinner, with but ten minutes to spare, "there was a stir in the chamber... a general pause in the room." Even the magnificent, haughty Marquess of Beaumanoir "seemed a little moved" in the presence of this "gentleman of distinguished air."14 Would it be farfetched to suggest that Disraeli himself would have liked to make such an entrance? Furthermore, Disraeli's choice of an Iberian background for Sidonia meant that he had to ignore what would have been obvious to a keen social observer like himself: a well-connected, cosmopolitan Sephardi banker was a socioeconomic anachronism in Victorian Britain. The heyday of Sephardi influence and opulence was long past. In the 1840 s, when Disraeli was writing Coningsby and Tancred, Spanish and Portuguese Jews were absent from the front ranks of City firms engaged in international finance. Sidonia was a ghost from the previous century, brought back to life to meet Disraeli's own needs. Most of the important Jewish houses - the Rothschilds chief among them - traced their origins to the Frankfurt ghetto, not the courts and estates of Castile and Aragon. Moreover, in its broad outlines, Sidonia's rise to financial preeminence after his arrival in England parallels that of the outstanding Ashkenazi banker of the period, Nathan Rothschild (1777-1836). In fact, Disraeli attributed Sidonia's success to having, like Rothschild, "a brother, or near relative, in whom he could confide, in most of the principal capitals" of Europe. ${ }^{15}$

In invoking the myth of Sephardi superiority, Disraeli tended to avoid explicit comparisons between Spanish and Portuguese Jews, on the one hand, and Polish and German Jews, on the other. ${ }^{16}$ The mere evocation of Sephardi grandeur was sufficient to indicate that an implicit and invidious comparison was being made, given the oft-remarked ties of London's Ashkenazim to low-status street trades. However, on at least two occasions, Disraeli went further. One was in the above-mentioned memoir of his father. The other was a longer passage, in Tancred, in which he contrasted the Sephardim of the sunny Mediterranean with the Ashkenazim of the bleak north, in Houndsditch and the Minories in London and the Judengassen of Hamburg and Frankfurt. Here he noted how the Sephardim, "in their beautiful Asian cities or in their Moorish and Arabian gardens," more easily celebrated and identified with the agricultural festivals of Judaism and their nature-based rites, like the building of sukkot, than the Ashkenazim in their squalid quarters in the icy climes of northern towns. Although he expressed admiration for the latter's steadfast devotion to "Oriental customs in the heart of our Saxon and Sclavonian cities," he described the typical Ashkenazi Jew as "an object... of prejudice, dislike, disgust, perhaps hatred." Imagine, he asked his readers,

... a being... born to hereditary insult, without any education, apparently without a circumstance that can develop the slightest taste, or cherish the least sentiment for the beautiful, living amid fogs and filth, never treated with kindness, seldom with justice, occupied with the meanest, if not the vilest, toil, bargaining for 
frippery, speculating in usury, existing for ever under the concurrent influence of degrading causes. ${ }^{17}$

In addition, Disraeli knew and used, in private at least, an epithet-like term to refer to Ashkenazim. In a letter to his father in December 1835, he wrote that the merchant banker Isaac Lyon Goldsmid (1778-1859), whom he had just met, was "not an ass in business, but a sharp Tedesco."18 This is, however, the sole occasion in his voluminous correspondence on which he used this pejorative term (which is not to say, of course, that he did not use it more often in conversation with family members). But for the most part Disraeli tended to praise Sephardim rather than disparage their northern counterparts, an understandable strategy in that he staked his claim to aristocratic status on the basis of the nobility of the Jewish race in general rather than one small part of it. In fact, at the end of the above-quoted passage in Tancred contrasting Sephardim and Ashkenazim, he praised the spiritual nobility of the latter in their attachment to ancient customs.

Although blessed with a fertile imagination, Disraeli neither created nor even much embellished the myth of Sephardi noble lineage. Rather, he made use of a well-established tradition, whose history has yet to receive the attention it merits. The oldest expression of the myth can be traced back to Muslim Spain, centuries before the expulsion, when it took the benign form of the genealogical claim that the Jews of Spain were galut yerushalayim asher be-sefarad, descendents of the royal tribe of Judah, of the inhabitants of Jerusalem whom Nebuchadnezzar had carried off to Babylonia at the end of the sixth century BCE. The emergence of a Jewish courtier elite, who served Spain's monarchs as tax-farmers, physicians, diplomats, astronomers, and political advisors, was seen as confirmation of their own noble origins. ${ }^{19}$ Although the theme of Judaean descent was later incorporated into versions of the myth, full-blown claims of superiority arose only in the last century of open Jewish life on the peninsula, in response to Iberian racial anti-Semitism. The mass conversions sparked by the pogroms of 1391 and the disputation of Tortosa in 1413-1414 created the basis for the entry of thousands of New Christians into offices of the church, the military, the universities, the royal courts, and the municipalities. Their rapid upward mobility provoked a backlash in Old Christian society, which at midcentury exploded in racial polemics against the New Christians. The Jewish religion having ceased to define difference in former Jews and their offspring, Old Christians came to believe that it was New Christian racial descent, their blood, their unalterable, baptism-proof essence, that constituted the source of their evil traits and explained, as well, their social and economic success. The introduction of the statutes of limpieza de sangre, beginning in 1449 and continuing through the mid sixteenth century, represented the institutionalization of the spreading belief that there were profound differences between the noble blood of Old Christians and the tainted blood of New Christians. ${ }^{20}$ 
One response was to counter Hispanic claims of descent with Jewish claims. On the principle that nobility derives from antiquity, Spanish Jews, including some converts, claimed that they were the noblest of all peoples, since they were able to trace their ancestry to Judaea and Jerusalem. The family of Pablo de Santa Maria (né Solomon Halevi), bishop of Burgos, who had converted in 1391, claimed descent from the family of Mary, mother of Jesus, while a converso family that had settled in Brazil claimed to possess a deed of nobility proving its descent from the Maccabees!21 Jews who went into exile in 1492 and never donned New Christian masks celebrated their descent as well. They also tended to idealize their own immediate past, a natural response to dislocation, recounting with pride (and exaggeration) the learning, wealth, wisdom, and influence of their ancestors, especially the courtier class. In this idealization of their former life, the Jewish communities of Spain, it was claimed, surpassed all other diaspora communities whatever the criteria. ${ }^{22}$ The rapid rise of the exiles to dominance in the Jewish communities of North Africa and the Balkans where they found refuge confirmed their sense of superiority - as did the subsequent "sephardicization" of these communities, that is, their adoption of the Sephardi minhag.

Conversos who returned to Judaism in northern and western Europe in the seventeenth and eighteenth centuries brought with them the Iberian discourse of noble lineage and racial separateness, as did, to a lesser extent, those few Sephardim from Italy and North Africa whose ancestors had fled in 1492 and who now migrated northward. ${ }^{23}$ As former New Christians worked to create new Jewish identities for themselves, they used these notions to help establish boundaries, to mark off who they were in relation to Christians in general, the Spanish and Portuguese in particular, and Jews from other lands, as well. Their sense of ethnic separateness was nourished even more by their face-to-face encounter, beginning in the seventeenth century, with Polish and German Jews, especially in Hamburg, London, and Amsterdam. Most Ashkenazim who reached these cities were poor and unskilled, with little prior exposure to western education, culture, and manners. A large number were Betteljuden - vagabonds and schnorrers, the flotsam and jetsam of the Ashkenazi world, persons without resources or fixed residence who wandered from community to community, begging, stealing, and in general living by their wits.

This encounter, between two groups of Jews whose historical experiences differed profoundly one from the other, bred contempt among Iberian Jews for their northern brethren and, at the same time, strengthened their obsession with lineage, descent, and blood and their desire to hold themselves aloof. In Amsterdam, the center of the western Sephardi diaspora, social ties between the two groups failed to develop; with a few exceptions, contacts remained at the instrumental level, between givers and receivers of relief or between masters and mistresses and their servants. ${ }^{24}$ The caste pride of the Amsterdam Sephardim manifested itself in discriminatory measures against Jews of non-Iberian origin 
from the mid seventeenth century on. In 1654, for example, the Amsterdam mahamad forbade Ashkenazi women (in effect, servants) from attending services in the Sephardi synagogue; in 1657, it banned non-Sephardim from studying in its communal school; in 1671, it prohibited Ashkenazim who married Sephardi women, as well as their offspring, from becoming yehidim (privileged members) or being buried in the Sephardi cemetery; in 1697, it revoked the membership of Sephardim who took non-Sephardi wives. Moreover, in 1632, in the hope of discouraging penniless Ashkenazim from settling in Amsterdam, the Spanish and Portuguese leadership prohibited its members from giving charity to beggars at their doors or the gate of the synagogue. In the mid $1630 \mathrm{~s}$, it also began repatriating German and Polish Jews. ${ }^{25}$ (The practice of sending the poorest members of the community to distant lands was first used against indigent Sephardim.) Not surprisingly, few mixed Ashkenazi-Sephardi marriages took place in Amsterdam, even as late as the mid nineteenth century. ${ }^{26}$

In London, where contact between the two groups was greater, the Bevis Marks authorities imposed humiliating conditions on the celebration of AshkenaziSephardi unions to express their displeasure. In 1745, when the gabbai Jacob Israel Bernal (d. ca. 1766) asked permission to be married to an Ashkenazi woman, the elders consented but stipulated that no member of the bet din or hazzan was to officiate, that the groom was not to be called to the Torah, that no mi-she-berakhs were to be made in his honor, and that no celebration of any kind was to be held in the synagogue. In other cases, permission to marry was denied or, when given, the name of the bride omitted from the marriage register, where she was listed as merely "Tudesca." The revised ascamot of 1784 prohibited the hakham from officiating at mixed marriages and barred Sephardim who married non-Sephardim or even the Sephardi widows of non-Sephardim from receiving communal relief. ${ }^{27}$

In the seventeenth century, Sephardi motives for distinguishing and segregating themselves from other Jews were internal: the emotional need to forge a new, non-converso group identity and the practical need to reduce the burden of caring for destitute newcomers from Central and Eastern Europe. In the eighteenth century, external motives as well came into play. Eager to advance their social integration and improve their legal status, Sephardi polemicists and apologists from the mid eighteenth century on displayed a lively concern with their public image. In particular, they tried to disassociate themselves from destitute German and Polish Jews then migrating westward in increasing numbers, whom, they believed, blackened the name of all Jews. The most famous example of this strategy is found in the reply of the political economist Isaac de Pinto (1717-1787) to Voltaire's vulgar remarks about Jews in his Dictionnaire philosophique. ${ }^{28}$ Pinto charged Voltaire with failing to distinguish between Spanish and Portuguese Jews and "la foule des autres enfans de Jacob." The former, he told Voltaire, were descendents of the tribe of Judah who migrated to Spain at the time of the Babylonian captivity. They scrupulously avoided 
mixing with and marrying other Jews and, though they shared the same religion, observed it differently, maintaining separate synagogues. Moreover, the manners and habits of the Portuguese were different. They did not have beards or distinctive dress, while the rich among them cultivated learning, elegance, and pomp to the same extent as other European nations. The gap between the Sephardim and other Jews was so great, he reported, that, if a Portuguese Jew in Holland or England were to wed a German Jewess, he would lose his communal privileges: he would lose his membership in the synagogue; he would be denied all religious honors; he would be cut off from the body of the nation; he would be refused burial among his Portuguese brethren. German and Polish Jews, on the other hand were degraded, having been deprived of the advantages of social contact, treated with contempt, persecuted, humiliated, and insulted through the ages. A Portuguese Jew from Bordeaux and a German Jew from Metz were "deux êtres absolument differens."29

When Jewish status was debated in France in the last years of the ancien régime and during the revolutionary and Napoleonic period, spokesmen for the Sephardi communities in southwestern France invoked this distinction repeatedly. For example, in a mémoire to the government in June 1788, Abraham Furtado (1756-1817) and Solomon Lopes-Dubec emphasized, as Pinto had earlier, the ease with which Sephardim assimilated to their adopted homes in northern and western Europe:

A Portuguese Jew is English in England and French in France, but a German Jew is German everywhere because of his customs from which he deviates rarely; thus one can look at the English and the Germans as brothers who, although sharing the same mother, have nevertheless developed characteristics which are absolutely different, nay even incompatible. ${ }^{30}$

In August 1806, when the so-called Napoleonic Sanhedrin in Paris composed its replies to twelve questions about Judaism's relationship to French citizenship, the first draft of its answer to question four - did Jews consider Frenchmen as brothers or strangers? - established a difference between Portuguese and German Jews. ${ }^{31}$ This strategy of differentiation bore fruit in the end: when Napoleon, disappointed by the failure of French Jews to "regenerate" themselves following emancipation, imposed new restrictions on Jewish commerce, conscription, and residence, he exempted the Sephardim. ${ }^{32}$

There is both indirect and direct evidence that Isaac D'Israeli (1766-1848) was not only familiar with but embraced the myth of Sephardi superiority. Even if an infrequent visitor to the synagogue in Bevis Marks, he was not a stranger to Sephardi society. His own father was an immigrant to England, like others in his family circle, and was in touch with social and cultural currents that flowed strongly in Sephardi communities abroad. As a teenager, he was sent to live in Amsterdam, with his father's agent there. It can also be inferred that he used the 
term "tudesco" - with all its negative associations; after all, from whom else did his son learn the term? In addition, a public debate about Jewish poverty and criminality took place in London in 1802 during which the Sephardi community disassociated itself from the rest of London's Jews. Following publication of a work critical of the Jewish poor, influential Ashkenazim proposed to Parliament the establishment of a Jewish relief board with the authority to tax Jewish ratepayers, centralize the distribution of charity, and jail and deport undesirable aliens. The Spanish and Portuguese community fought inclusion in the scheme, instructing their attorney to see that their name was not connected with it. ${ }^{33}$ In a document prepared for a member of parliament who was assisting them, they emphasized that the Portuguese and the Germans formed "two distinct (not religious, but) political bodies," that they "always considered each other (as they actually are) separate and distinct bodies." 34 There is no reason to doubt that Isaac D'Israeli, who had written about the reform of Jewish culture in a biographical sketch of Moses Mendelssohn in the Monthly Magazine in 1798, was aware of this debate. A few years later, when the Parisian Sanhedrin convened, he followed its proceedings, publishing two articles about the assembly, again in the Monthly Magazine. ${ }^{35}$

The most compelling evidence that Isaac was the conduit through which the Sephardi myth reached Benjamin is in Isaac's anonymous treatise The Genius of Judaism (1833). Using similes, rhetorical devices, and illustrations lifted, without acknowledgment, from Isaac de Pinto's Apologie, D'Israeli restated the claim that the Jews were not one but several nations, each, like the chameleon, reflecting the color of the spot they rested on (the simile was Pinto's). ${ }^{36}$ Thus: "After a few generations, the Hebrews assimilate with the character, and are actuated by the feelings, of the nation where they become natives." The first Jews to settle in England, he told his readers, were Spanish and Portuguese Jews - "noblemen, officers, learned physicians, and opulent merchants" - who brought with them "their national characteristic... their haughtiness, their high sense of honour, and their stately manners." Subsequent Jewish immigrants from Germany and Poland were "a race in every respect of an inferior rank."

The Portuguese Grandees shrunk from their contact; they looked on those lees of the people in bitter scorn, and through a long century the contumely was never forgiven. In every respect these differing races moved in contrast. The one opulent and high-minded; the other humiliated by indigence, and pursuing the meanest, and not seldom the most disreputable, crafts. The one indolent, polished, and luxurious; the other, with offensive habits, active and penurious, hardy in frame, and shrewd in intellect. The one splendid in dress and equipage, while the abject Polander still retained the beard commanded by Moses with the gabardine.

Between the two groups, mutual hatred flourished. D'Israeli even claimed that "the haughty Lusitanian Jew would have returned to the fires of Lisbon, ere he condescended to an intermarriage with the Jew of Alsace or Warsaw." 37 If, as 
widely acknowledged, Isaac's Tory and royalist sympathies influenced his son's interpretation of English history, it is also probable that his Jewish prejudices left their mark as well. It is no coincidence that Benjamin Disraeli used images and terms similar to those his father used in describing the cultural and social gulf between the two communities.

In tracing this tradition from late-medieval Spain to Victorian England, I do not intend to suggest that it, rather than some other influence, is the hitherto unknown key to Disraeli's racial thinking. Multiple cultural and intellectual currents, especially those of a romantic hue, oversaw its genesis. Disraeli belonged to a broad stream of conservative, romantic, organic thought in Britain that hated Benthamite utilitarianism, free market economics, and liberal doctrines of progress. His ideological bedfellows included Walter Scott, Robert Southey, A. W. N. Pugin, Thomas Carlyle, and, to a lesser extent, collectors of old armor, builders of battlemented, asymmetrical, picturesque castles, and enthusiasts of the chivalric revival. Moreover, while full-blown deterministic racial theories were rare when Disraeli's outlook was taking shape, inchoate notions of racial hierarchy were not. The discourse of Anglo-Saxonism was widely diffused in the first half of the nineteenth century. ${ }^{38}$ The author of The English and Their Origins, writing in 1866, noted that there were few educated Englishmen who had not been taught as children that "the English nation is a nation of almost pure Teutonic blood," that its constitution, customs, wealth, and empire were the necessary result of "the arrival, in three vessels, of certain German warriors" centuries earlier. ${ }^{39}$ Isaac D'Israeli's close friend Sharon Turner, who convinced him to make his children Christians and afterward took them to St. Andrew's, Holborn, to be baptized, was author of a bestselling multivolume History of the Anglo-Saxons (1799-1805) that was shot through with a racial reading of English history. ${ }^{40}$

If racial ideas were "in the air," it also must be recalled that Disraeli's own needs prepared him to absorb them. Driven by ambition but unable to shake his Jewish origins (like the conversos before him), he discovered that the idea of race, when given a novel, "Jewish" twist, allowed him to counter the hereditary claims of the great English landed families. His ancestral community's obsession with descent helped to determine his novel response, while infusing it at the same time with an Iberian flavor. Without reference to this myth and its history, the Sephardi component of his Jewish chauvinism is inexplicable.

Disraeli's reaction to the prejudice that he continued to encounter after his baptism was unusual. No other Victorian Jew, baptized or otherwise, opted for such a strategy. Jews in Britain (and elsewhere, as well) who desired entrée to Christian circles hid, minimized, or, at most, did not call attention to their Jewishness, even when it was thrown in their faces. To paraphrase Heine, Jewish chauvinism was not their ticket of admission into European society. Their hopes 
for inclusion rested, instead, on non-biological, liberal theories of social behavior and historical development that stressed nurture over nature, the malleability of manners, traits, and character, and, in particular, the similarity of Jews to other persons in all spheres of human activity other than religion.

Given the eccentric character of Disraeli's response, one is tempted to discount its historical importance, to consider it a bizarre, though entertaining, footnote to the main text of English Jewish history. After all, if his use of the idea of race was unrepresentative - which, indeed, it was - then what is its larger historical relevance, its connection to broader historical themes? Of course, one could argue that Disraeli's solution, however peculiar, is one more telling example of how difficult it was for even well-acculturated Jews to avoid anti-Semitic obstacles on the road to integration. And this is fair enough. But there is another, more important historiographical dimension to Disraeli's Jewish chauvinism that comes into focus when his use of the myth of Sephardi superiority is emphasized. For while his racial ideas were untypical, his invocation of the Sephardi myth was not.

From the late-eighteenth century, Sephardim throughout western Europe, as well as Ashkenazim, deployed the myth to promote their own cultural, political, and social agendas. As we saw, Sephardi spokesmen used it repeatedly to disassociate themselves from Jews who, in their view, threatened their own status. In the German states, the pioneers of Wissenschaft des Judentums and the leaders of the Reform movement constructed an image of Sephardi Judaism that stressed its cultural openness, philosophical rationalism, and aesthetic sensibilities in order to criticize what they disliked in their own tradition, i.e., its backwardness, insularity, aversion to secular studies. In France, Austria, Germany, Hungary, and the United States, communal and congregational boards erected imposing synagogues of so-called Moorish design, assertive symbols of their break with the "unenlightened" Ashkenazi past. Jewish poets and novelists who were Disraeli's contemporaries - Heinrich Heine (1797-1856), the brothers Phöbus (1807-1870) and Ludwig (1811-1889) Philippson, Berthold Auerbach (1812-1882), and Grace Aguilar (1816-1847) - were fascinated by the Iberian experience and drew on it for themes and subjects, with the result that their work further augmented its mystique. ${ }^{41}$

Before the end of the century, the myth of Sephardi superiority was widely disseminated and available for appropriation by Jews and their enemies alike. In his attack on the historian Heinrich Graetz (1817-1891) in 1881, Heinrich von Treitschke (1834-1896) maintained that the Spanish and Portuguese Jews were closer to the German people than were the Jews of Poland and Germany because their history was prouder and more distinguished than that of the latter, who had been scarred by centuries of Christian tyranny. In their battle against racial myths about Jewish deformities, Jewish anthropologists drew on the Sephardi mystique to create a countermyth of their own - that of the well-bred, aesthetically 
attractive, physically graceful Sephardi, a model of racial nobility and virility. In their work, John Efron notes, "the Sephardi served as the equivalent of the Jewish 'Aryan'... the physical counterpart to the ignoble Jew of Central and Eastern Europe." For some acculturated Ashkenazim who wished to distance themselves from impoverished East European Jews and their alleged defects, fantasies of Sephardi descent became a strategy for enhancing their own self-image. Theodor Herzl (1860-1904), whose attitudes toward Jews vacillated between pride and disdain, claimed Iberian roots for his family. He told the early English Zionist Jacob de Haas (1872-1937) that his paternal grandfather was a Spanish Jew who had been forced to convert to Christianity and had later fled to Constantinople, where he reembraced Judaism. In a different version, told to the Hebrew and Yiddish writer Reuben Brainin (1862-1939) in 1904, he traced his descent to a high-ranking converso monk who returned to Judaism while abroad on a mission. ${ }^{42}$

In a structural sense as well, Disraeli's use of the Iberian Jewish mystique resembled other assimilationist strategies in the age of emancipation. Westernized, upper-middle-class Jews unsure of their social status routinely made public declarations that Jews fell into two categories, "good" Jews and "bad" Jews. In England, native-born Jews in the period of mass migration struggled to distance themselves from impoverished, Yiddish-speaking, foreign-born newcomers, while Bayswater and Mayfair Jews poured scorn on their less cultured coreligionists in Maida Vale. These distinctions, conveyed in novels, tracts, newspapers, lectures, and other public forums, were intended to convince the gentile world that their authors, "good" Jews, were nothing like "bad" Jews and thus merited political rights, social acceptance, exemption from contempt, or whatever was on the agenda at the time. ${ }^{43}$ In this sense, the Disraelian strategy was all too representative.

\section{NOTES}

Author's note: I would like to thank my colleagues Zvi Gitelman and Miriam Bodian for their comments and advice on an earlier version of this article.

1. Battersea Papers, Add MSS 47910/5, British Library, London.

2. Stephen R. Graubard, Burke, Disraeli, and Churchill: The Politics of Perseverance (Cambridge, MA, 1961), 123; Robert Blake, Disraeli (Garden City, NY, 1968), 47. Blake's observation reveals more about him than it does about Disraeli.

3. Hannah Arendt, Antisemitism, part 1 of The Origins of Totalitarianism (New York, 1968), 72-5.

4. Berlin's "Benjamin Disraeli, Karl Marx and the Search for Identity" appeared initially in the Transactions of the Jewish Historical Society of England 22 (1970): 1-20. It was reprinted in Midstream 16/7 (August-September 1970): 24-49, and in a collection of Berlin's essays, Henry 
Hardy (ed.), Against the Current: Essays in the History of Ideas (New York, 1979), 252-86. Translations have appeared in French, German, and Spanish.

5. Paul Smith, "Disraeli's Politics," Transactions of the Royal Historical Society, 5th ser., 37 (1987): 65-85; John Vincent, Disraeli, Past Masters series (Oxford, 1990); Stanley Weintraub, Disraeli: A Biography (New York, 1993).

6. See, e.g., Richard Shannon, "The Cult of the Prophet," Times Literary Supplement, 29 November 1993, 3-4.

7. See also Abraham Gilam, "Disraeli in Jewish Historiography," Midstream 26/3 (March 1980): 24-29; idem, "Benjamin Disraeli and Jewish Identity," The Wiener Library Bulletin, n.s., 33/51-52 (1980): 2-8; Benjamin Jaffee, "A Reassessment of Benjamin Disraeli's Jewish Aspects," Transactions of the Jewish Historical Society of England 27 (1982): 115-23; M. C. N. Salbstein, The Emancipation of the Jews in Britain: The Question of the Admission of the Jews to Parliament, 1828-1860 (Rutherford, NJ, 1982), chap. 5 ("Benjamin Disraeli, Marrano Englishman”); Todd M. Endelman, “Disraeli's Jewishness Reconsidered," Modern Judaism 5 (1985): 109-23. Salbstein alone mentions Disraeli's invocation of alleged Sephardi superiority.

8. The most reliable account of Disraeli's ancestry is Cecil Roth, Benjamin Disraeli, Earl of Beaconsfield (New York, 1952), chap. 1. See also Michael Selzer, 'Benjamin Disraeli's Knowledge of his Ancestry," Disraeli Project Newsletter 1/2 (1976): 8-17.

9. Benjamin Disraeli, "On the Life and Writings of Mr. Disraeli," in Isaac D'Israeli, The Curiosities of Literature, new ed., 3 vols. (London, 1858), vol. 1: viii-ix.

10. John Vincent (ed.), Disraeli, Derby and the Conservative Party: Journals and Memoirs of Edward Henry, Lord Stanley, $1849-1869$ (Hassocks, Sussex, 1978), 32.

11. Quoted in Weintraub, Disraeli, 377.

12. M. G. Wiebe et al. (eds.), Benjamin Disraeli Letters, vol. 4, 1842-1847 (Toronto, 1989), 153.

13. Benjamin Disraeli, Coningsby; or The New Generation, bk. 4, chap. 10.

14. Ibid., chap. 9 .

15. Ibid., chap. 10.

16. John Vincent comments that as a rule "Disraeli said little about the lower races; his object was to praise, not disparage." Disraeli, 27.

17. Benjamin Disraeli, Tancred; or The New Crusade, bk. 5, chap. 6.

18. J. A. Gunn et al. (eds.), Benjamin Disraeli Letters, vol. 2, 1835-1837 (Toronto, 1982), 109. The word "tudesco" (to use the more common Sephardi orthography) is an iberianized form of the Italian word "tedesco" (German), used by western Sephardim to refer to Jews from Germany and Poland. Although at first non-pejorative, it became, by the eighteenth century at the latest, a term of contempt, expressing disdain for persons considered to be of low, even disreputable, rank. I am grateful to Miriam Bodian, whose own research and writing focus on the Sephardi diaspora, for clarifying this for me.

19. Haim Hillel Ben Sasson, "Dor golei sefarad al atsmo" (The Generation of Spanish Exiles on its Fate), Zion 26 (1961): 23.

20. Yosef Hayim Yerushalmi, Assimilation and Racial Anti-Semitism: The Iberian and the German Models, The Leo Baeck Memorial Lecture 26 (New York, 1982).

21. Miriam Bodian, "Men of the Nation': The Shaping of Converso Identity in Early Modern Europe," Past \& Present 143 (May 1994): 62.

22. Ben Sasson, "Dor golei sefarad," 23-29.

23. On the Iberian legacy of caste pride among western Sephardim, see Yosef Kaplan, Mi-natsrut le-yahadut: hayyav u-fealo shel ha-anus Yitshak Orobio de Castro (From Christianity to Judaism: The Life and Work of Isaac Orobio de Castro) (Jerusalem, 1982), 269-74; idem, "Political Concepts in the World of the Portuguese Jews of Amsterdam during the Seventeenth Century: The Problem of Exclusion and the Boundaries of Self-Identity," in Yosef Kaplan, Henry Méchoulan, and Richard H. Popkin (eds.), Menasseh ben Israel and His World (Leiden, 1989), 45-62. 
24. Yosef Kaplan, "Yahasam shel ha-yehudim ha-sefaradim ve-ha-portugalim li-yehudim ha-ashkenazim be-amsterdam be-meah ha-17" (The Relationship of Spanish and Portuguese Jews to Ashkenazi Jews in Amsterdam in the Seventeenth Century), in Shmuel Almog et al. (eds.), Temurot ha-historiyah ha-yehudit ha-hadashah: kovets maamarim shay le-Shmuel Ettinger (Transformations in Modern Jewish History: Essays Presented to Shmuel Ettinger) (Jerusalem, 1987), 399.

25. Kaplan, "Yahasam," 403-406; idem, "The Portuguese Community in 17th-Century Amsterdam and the Ashkenazi World," in Jozeph Michman (ed.), Dutch Jewish History, vol. 2 (Jerusalem, 1989), 33-34, 43-44.

26. Jozeph Michman, "Beyn sefaradim ve-ashkenazim be-amsterdam" (Between Ashkenazim and Sephardim in Amsterdam), in Issachar Ben Ami (ed.), Moreshet yehudei sefarad ve-ha-mizrah (The Sephardic and Oriental Jewish Heritage) (Jerusalem, 1982), 136-37.

27. Albert M. Hyamson, The Sephardim of England: A History of the Spanish and Portuguese Jewish Community (London, 1951), 170-71, 190, 228. Hyamson claims that the authorities' motivation was a concern "lest the numbers of these individuals [non-Sephardim] should become too large so as perhaps to threaten the preservation of their Community as a Sephardi one" (170).

28. Isaac de Pinto, Apologie pour la nation juive, ou, réflexions critiques sur le premier chapitre du VII. tome des oeuvres de monsieur de Voltaire au suject des Juifs (Amsterdam, 1762). On Pinto's work in general and the genesis of his apology in particular, see Arthur Hertzberg, The French Enlightenment and the Jews (New York, 1968), 142-53, 180-83, 269-70.

29. Pinto, Apologie, 12-16.

30. Quoted in Frances Malino, The Sephardic Jews of Bordeaux: Assimilation and Emancipation in Revolutionary and Napoleonic France (University, AL, 1978), 32.

31. Diogene Tama (ed.), Transactions of the Parisian Sanhedrim, trans. F. D. Kirwan, mimeographed ed. (Cincinnati, 1956), 19.

32. The campaign of the Sephardim to secure exemption is described in Malino, Sephardic Jews of Bordeaux, 95-109.

33. Todd M. Endelman, The Jews of Georgian England, 1714-1830: Tradition and Change in a Liberal Society (Philadelphia, 1979), 231-36.

34. The document is reproduced in full in Charles H. L. Emanuel (ed.), A Century and a Half of Jewish History Extracted from the Minute Books of the London Committee of Deputies of the British Jews (London, 1910), 10-12.

35. [Isaac D'Israeli], "A Biographical Sketch of the Jewish Socrates," Monihly Magazine, vol. 6, pt. 2 (1798): 38-44; "On the Late Installation of a Great Sanhedrim of the Jews in Paris," ibid., vol. 24, pt. 2 (1807): 34-38; "Acts of the Great Sanhedrim at Paris," ibid., 134-36, $243-48$.

36. It is impossible to know whether Isaac D'Israeli owned a copy of the Pinto work. In the Rothschild Archive in London, there is a list of books from the library of Benjamin Disraeli that his heirs sold in 1881 [DFamE(1)/9A]. (Lord Rothschild was executor of his will.) The list contains fifty-four entries, most on Jewish themes. Given the large number of eighteenth-century publications, it seems reasonable to conclude that many belonged to Isaac initially. The Pinto work is not among them. However, this does not prove that Isaac did not own a copy, since it was a pamphlet, not a book, and the Jewish tracts in the collection, covering the years 1747 to 1794 , were bound together into two volumes and identified only with the words "various authors" and "various publishers." I am grateful to Melanie Aspey, archivist at the Rothschild Archive, for providing me with a photocopy of the list.

37. [Isaac D'Israeli], The Genius of Judaism (London, 1833), 237-8, 244-8.

38. Hugh A. MacDougall, Racial Myth in English History: Trojans, Teutons, and Anglo-Saxons (Hanover, NH, 1982), chap. 5; Leon Poliakov, The Aryan Myth: A History of Racist and Nationalist Ideas in Europe, trans. Edmund Howard (New York, 1977), 50-2.

39. Luke Owen Pike, The English and Their Origins (London, 1866), 15. 
40. MacDougall, 94.

41. Ismar Schorsch, "The Myth of Sephardi Supremacy," Leo Baeck Institute Year Book 34 (1989): 47-66; Ivan Marcus, "Beyond the Sephardi Mystique," Orim: A Jewish Journal at Yale 1/1 (1985): 35-53.

42. Walter Boehlich (ed.), Der Berliner Antisemitismusstreit (Frankfurt a.M., 1965), 37-8; John M. Efron, "Scientific Racism and the Mystique of Sephardi Racial Superiority," Leo Baeck Institute Year Book 38 (1993): 75-96; Jacques Kornberg, Theodor Herzl: From Assimilation to Zionism (Bloomington, 1993), 76-7.

43. See, for example, Todd M. Endelman, "The Frankaus of London, 1837-1967: A Study in Radical Assimilation," Jewish History/Historiyah Yehudit 8/1-2 (1994): 1-38.

University of Michigan 